\title{
FOREIGN DIRECT INVESTMENT (FDI) IN RETAIL IN INDIA: RAISON DETRE OF GROWTH
}

\author{
Dr. Arun Bhadauria \\ Assistant Professor, Amity University Uttar Pradesh \\ drarunbhadauria@gmail.com \\ Dr. Sachin Kumar Srivastava* \\ Assistant Professor, Amity University Uttar Pradesh \\ contact2sachinsrivastava@gmail.com \\ ${ }^{*}$ Correspondence author
}

\begin{abstract}
According to the Investment Commission of India, the retail sector is expected to grow almost three times its current levels to $\$ 660$ billion by 2015 . Investments are sought by Indian Retailers also to get necessary push for evolution of organized retailing in India, which has been much slower as compared to rest of the world. This is significant to mention that despite of the on-going wave of incessant liberalization and globalization the absence of political will to attract advanced technology and to adopt new retail format is holding retail revolution. FDI in Indian Economy is present since ages, though it is revealed from the chart that there are some states and cities where FDI inflows are larger in comparison of rest of the India. Maharashtra, Tamilnadu, Delhi, Karnataka and Andhra Pradesh are attracting two third of the total investment being the main centers of IT development in last 15 years. Moreover, on city to city basis, it is revealed that there is huge segregation in the inflows as more than 50 percent inflows are dropping in few cities Bangloru, Mumbai and National Capital Region (NCR).
\end{abstract}

Keywords: Foreign Direct Investment, Retail Segment, consumer perception, branding in retail, expansion Capabilities.

\section{Council for Innovative Research}

Peer Review Research Publishing System

Journal: International Journal of Research in Education methodology

Vol. 7, No.2

iiremeditor@gmail.com

www.ijrem.com 


\section{Indian Economy: paradigm shift towards mass consumerism}

Indian Economy is considered one of the rapidly growing economies in the world as evident from the attention it grabbed from all corners in the global economy. The recent spur in growth specially sectoral growth rate revealed the growth spree across newly emerging sectors such as Fast Manufacturing Consumer Goods (FMCG) including wholesale \& Retail, Information Technology Enabled Services (ITES), health and education. It is well cited that performance in post recession period has been dismal and economy has lost pace of growth cited earlier. However, under the new regime the recovery is anticipated. There were several obvious reasons for the debacle and certain steps taken by new government are pushing economy back on the path of development. In the previous regime opening up of the economy for rest of the world has been the centre of discussion. It was believed that to open up the retail trade sector to foreign investment was a change ushered in by policy makers to project Indian Economy as ever expanding market in order to attract investment in technology and innovation ${ }^{1}$. Still Indian masses, business class, and even policy makers carrying strong voting politics led reservations towards this issue considering employment opportunities, procurement from international market, competition and loss of share of local entrepreneurs are oblivion and doing away their fear by constantly debating the issue in public domain. Government tried to show some courage in a series of moves to open up the retail sector slowly to Foreign Direct Investment (FDI) but finding very difficult to make inroads amidst strong opposition on account of lack of strategy and defined road map. Recently Government has also brought up major policy change in terms of FDI in various sectors especially in defense and railways ${ }^{2}$.

According to the Investment Commission of India ${ }^{3}$, the retail sector is expected to grow almost three times its current levels to $\$ 660$ billion by 2015 . Investments are sought by Indian Retailers also to get necessary push for evolution of organized retailing in India, which has been much slower as compared to rest of the world. This is significant to mention that despite of the on-going wave of incessant liberalization and globalization the absence of political will to attract advanced technology and to adopt new retail format is holding retail revolution. This paper is genuine effort to evaluate the willingness of domestic retailers both organized and unorganized and experts under the various stimuli present and ongoing issues where some are real while many are simply preoccupied.

\section{Review of Literature}

N.V.Shaha and M.A.Shinde $2013^{4}$ have analyzed the India being a signatory to World Trade Organization's General Agreement on Trade-in Services, which includes wholesale and retailing services, had to open up the retail trade sector to foreign investment. There were initial reservations towards this issue arising from fear of job losses, procurement from international market, competition and loss of entrepreneurial opportunities to locals. However, the government in a series of moves opened up the retail sector slowly to Foreign Direct Investment (FDI).

Gaurav Bisaria $2012^{5}$ has discussed about various modes of Foreign Direct Investment (FDI) in retailing in India. FDI or foreign investment refers to the net inflows of investment to acquire a lasting management interest (10 percent or more) in an enterprise operating in an economy other than that of the investor. Foreign direct investment is the sum of equity capital, reinvestment of earnings and other long or short term capital as shown in the balance of payments. It usually involves participation in management, joint venture, transfer of technology and expertise.

Himani Tyagi $2012^{6}$ Retailing is one of the world's largest private industries. Liberalizations in FDI have caused a massive restructuring in retail industry. The benefit of FDI in retail industry superimposes its cost factors. Opening the retail industry to FDI will bring forth benefits in terms of advance employment, organized retail stores, availability of quality products at a better and cheaper price. It enables a countries product or service to enter into the global market.

\section{Research Methodology}

Analytical, descriptive and comparative methodology was adopted for this study. To make study more pressing and direct reliance has been equally distributed on primary and secondary data sources such as books, journals, newspapers and online database. However, the interpretation of the data and suggestions made assume importance for the healthy growth of the retail sector in the country.

For the convenience of study and the topic it was assumed on the basis of deliberations in the above segment of the paper departmental stores are most sought avenue for FDI and local kirana stores are going to face more competition.

Sample Size: 200,

Sampling Technique: Purposive Random Sampling, Population: Finite, Data Collection Instrument: Observation, Interview and Questionnaire, Demographic: Three categories were selected
1. Customers
2. Retailers (Organized \& Unorganized)
3. Experts

Geographic Location: Luck now, U.P. INDIA

Analysis:

Brand Value was taken as dependent variable because FDI seems to be attracted by organized branded retailers in both single retail and multi brand retail segments and its relations was studied with three other variables. Moreover, perception 
of retailers, customers and experts was also taken into reference for detailed analysis using correlation, regression tabular presentation.

So far the FDI in Indian Economy is concerned following statistics is important to confirm necessary initializing of the FDI in various sectors economically, geographically and inter-sectoral basis.

\section{FDI in India: Schematic Representation}

Foreign Direct Investment in India most sought and debated issue after the inception of New Economic Reforms and policy of Liberalization, Privatization and Globalization (LPG). The issue of FDI in retail though debated strongly on the issues of employment and losses of local small entrepreneurs is diagonally related to the other aspects of mass consumerism, socio-economic development and transforming economy. Before going in detailed discussion of the various dimension of FDI in retail pertaining to consumer perception this will be better to provide adequate insight of the FDI in India since ages

\subsection{FDI: Pathways and Servicing}

In Indian Economy FDI and other investments are routed through strict governmental control. There are distinct pathways for various investments but automatic route is opened for FDI. (Fig-1)

Part - I

Foreign Investments in India-Schematic representation :

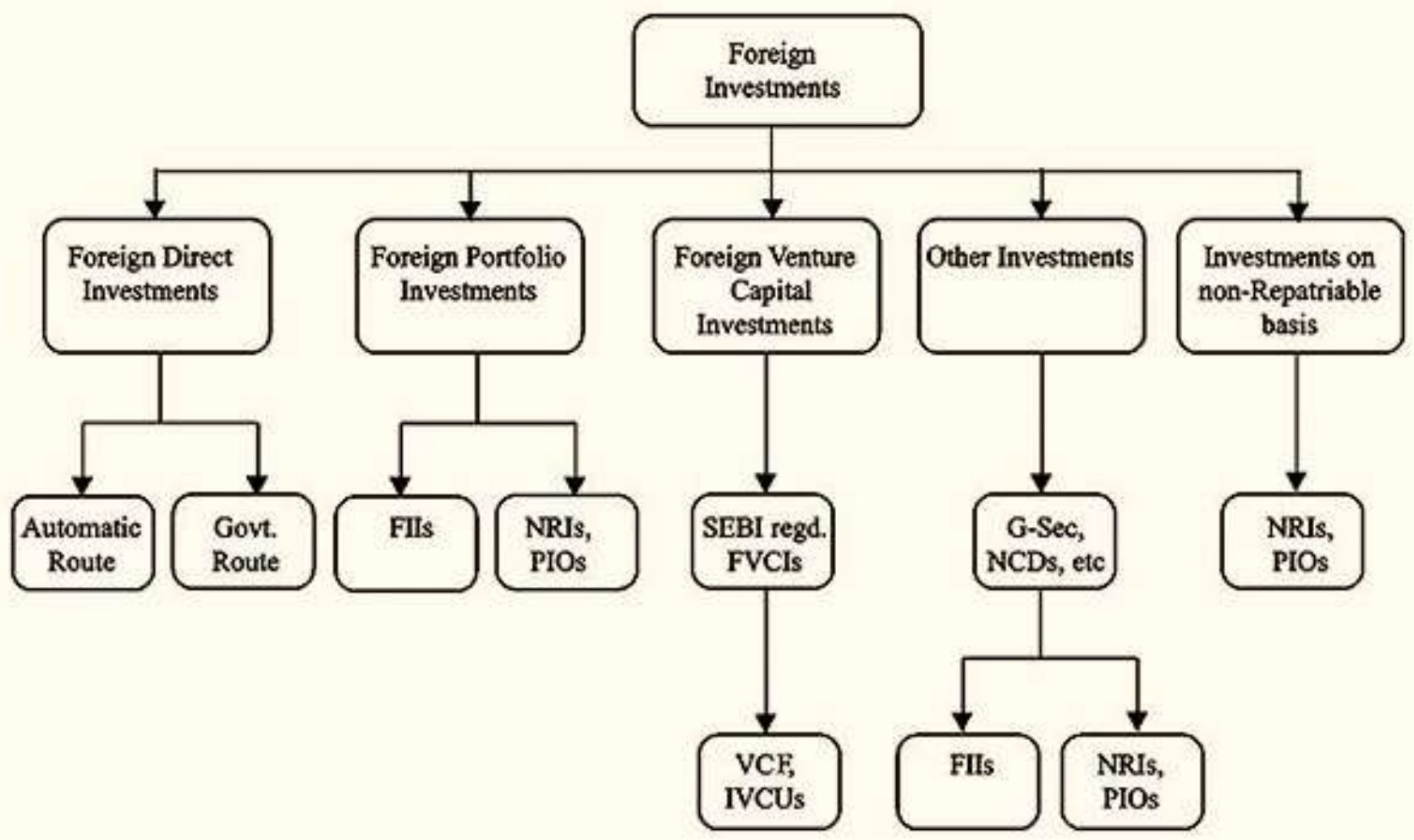

Source: http://indialiaison.com/fdifinal.htm March 13, 2015

Fig-1 Schematic Representation of Foreign Investments in India

\subsection{Regional FDI flow in India}

FDI in Indian Economy is present since ages, though it is revealed from the chart that there are some states and cities where FDI inflows are larger in comparison of rest of the India. Maharashtra, Tamilnadu, Delhi, Karnataka and Andhra Pradesh are attracting two third of the total investment being the main centers of IT development in last 15 years. Moreover, on city to city basis, it is revealed that there are huge segregation in the inflows as more than 50 percent inflows are dropping in few cities Bangloru, Mumbai and National Capital Region (NCR) (Fig-2). 


\section{Regional Flow of FDI in India}

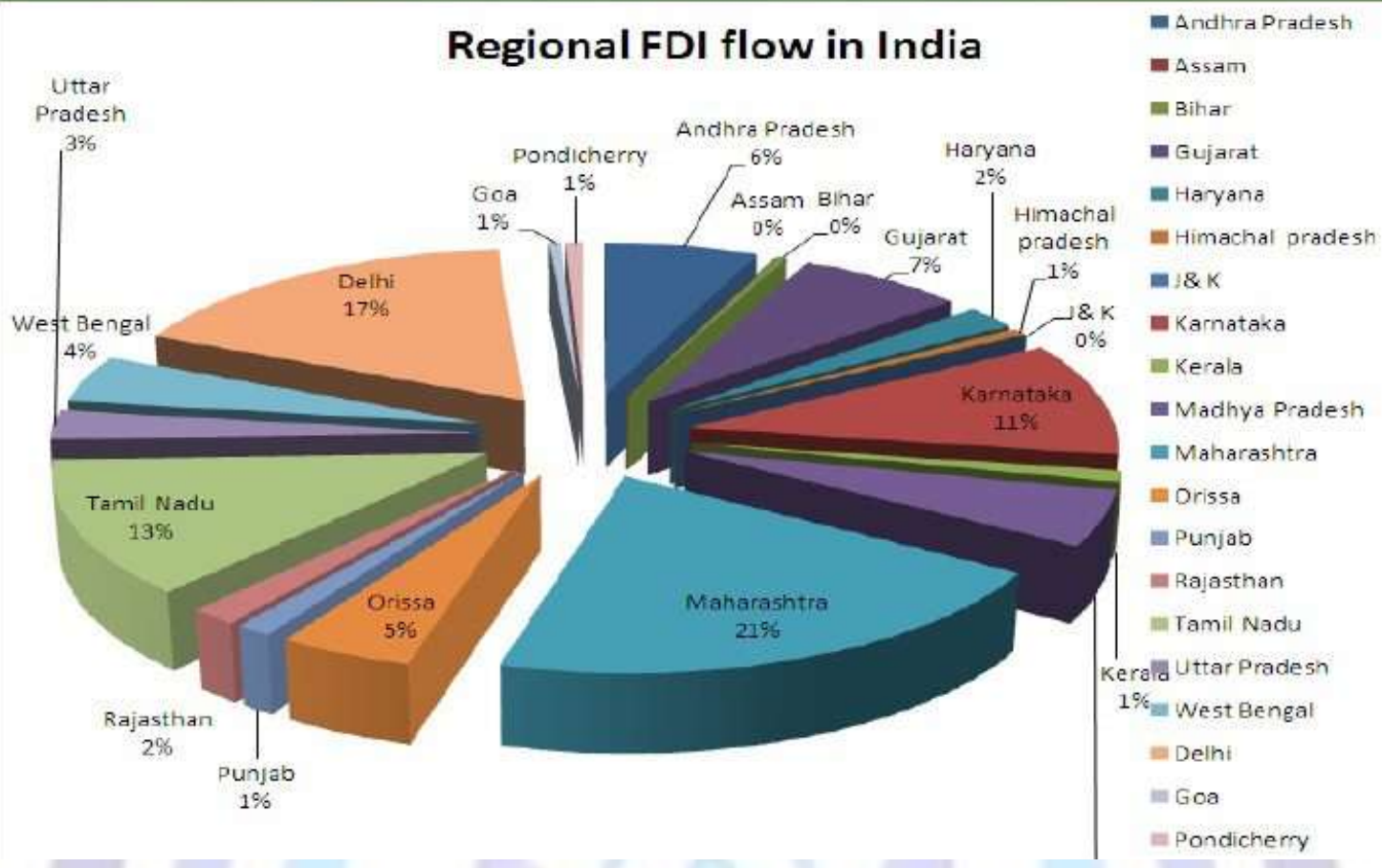

Source: http://www.slideshare.net/PeriasamyKandasamy/fdi-in-india-an-analysis March 13, 2015

Fig-2 Geographic representation of Foreign Investments in India
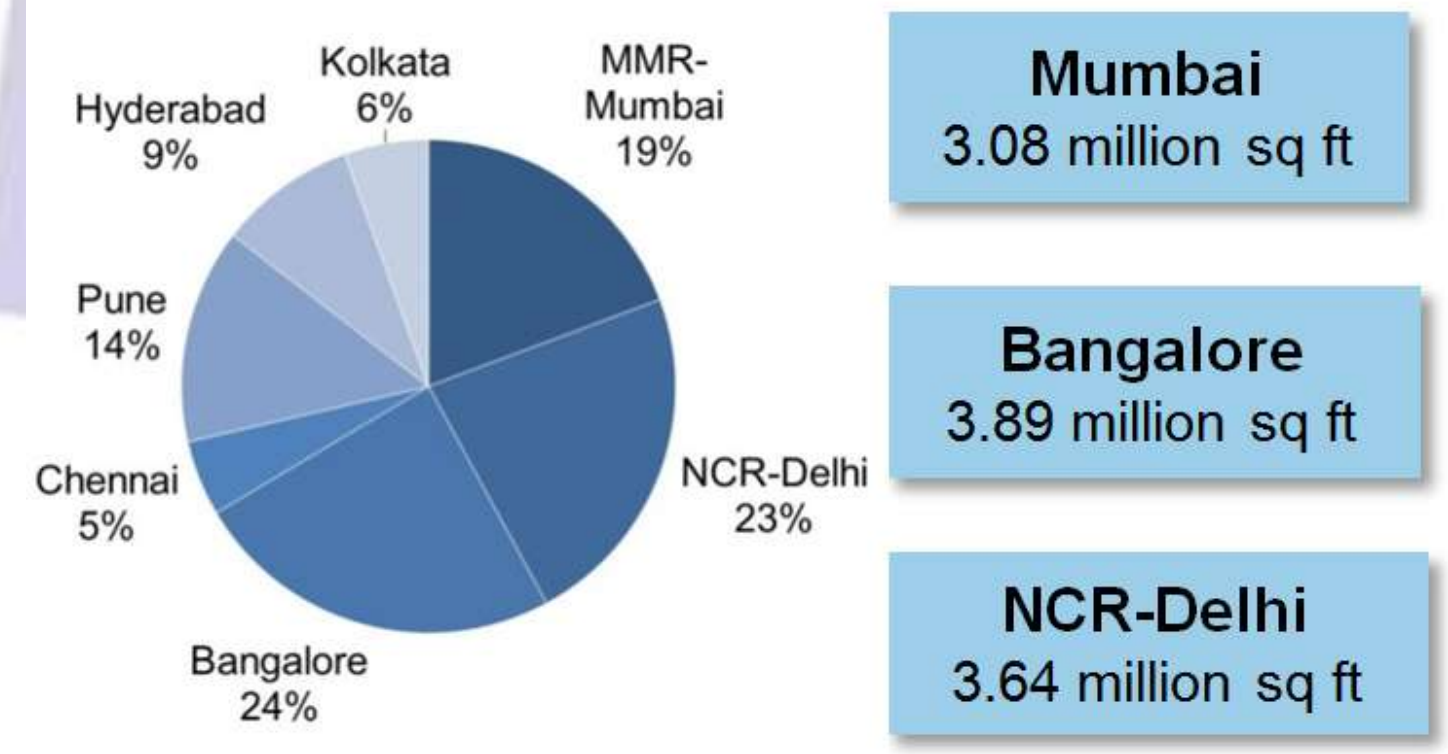

Source: http://www.thewadhwagroup.com/newsletters/september/roundup.html

Fig 3 FDI in Major City Centres in India 
- World Trade Organization's General Agreement on Trade in Services, which includes both wholesale and retailing services, came into effect

1997

- FDI in cash and carry (wholesale) with 100 percent rights allowed under the government approval route

\section{6}

- FDI in cash and carry (wholesale) brought under the automatic route

- Up to 51 percent investment in a single-brand retail outlet permitted, subject to Press Note 3 (2006 Series)

\section{1}

\section{- 100 percent FDI in single-brand retail permitted}

Source: http://www.india-briefing.com/news/foreign-direct-investment-indias-single-multibrand-retail-5232.html/

Fig-4 Series of steps to open up FDI for various sectors in India

It is evident from the regional inflow of the FDI that FDI is not sector specific rather business specific and route plays an important role. In case it is automatically routed the investment surge if visible. Citing the approval and actual turn up of investment in domestic circuit clearly reveals the inflows intensity. Despite of 100 percent approval in cash and carry inflows are meager till date because the investments are routed through government approval (http://indialiaison.com/fdifinal.htm March 13, 2015).
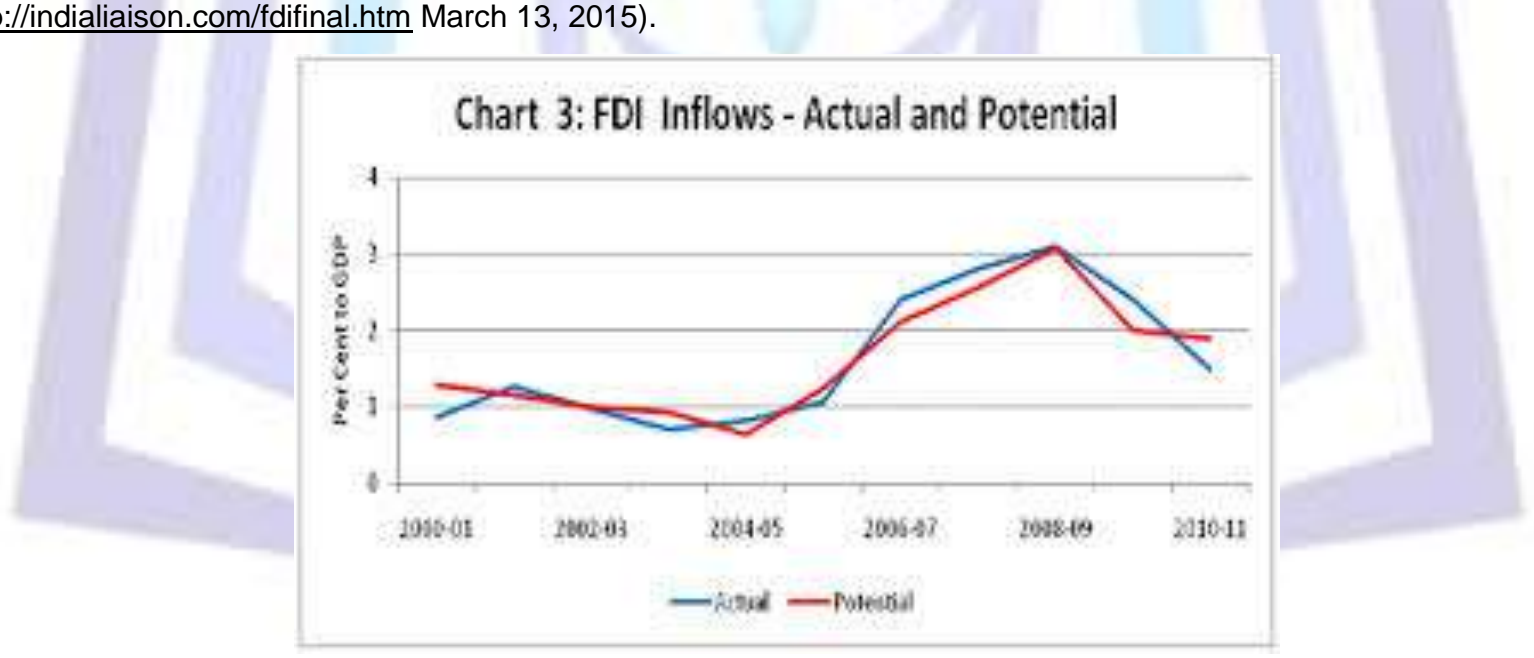

Source: $\underline{\text { http://www.rbi.org.in/scripts/bs viewcontent.aspx? } \mathrm{ld}=2513}$

Fig 5 FDI inflows

\subsection{FDI inflows and need of the hour}

The need of the foreign investments in every economy more or less depends upon its capital formation economic growth. The growth accompanied by foreign investments in the form of technology and monetary terms always desirable and pushes economy forward. The adjoin figure clearly reveals potential of FDI in India increased in the last 10 years which could not be converted into actual investment.

\subsection{FDI in various sectors}

FDI ironically was not realized in equal terms despite of being approved absolutely routed through many ways. Barring 4-5 sectors such as telecom, advertising and pharmaceutical sector FDI in figures has not been very attractive. Even in telecom foreign companies are facing lot of structural problems in operations and distribution. Here it is advisable that Indian Retail Sector and its structure is going to be major factor in attracting investment. 
Table - 1 FDI limit in various sector till date

\begin{tabular}{|l|l|}
\hline Sector & Percentage \% \\
\hline Telecom & 74 \\
\hline Banking & 74 \\
\hline NBFC & 100 \\
\hline Insurance sector & 26 \\
\hline Private petrol refining & 100 \\
\hline Construction development & 100 \\
\hline Coal and Lignite & 74 \\
\hline Electricity & 100 \\
\hline Pharmaceutical & 100 \\
\hline Transportation infrastructure & 100 \\
\hline Mining & 74 \\
\hline Advertising & 100 \\
\hline Airport & 74 \\
\hline Film production & 100 \\
\hline Pollution control & 100 \\
\hline $\begin{array}{l}\text { Print media } \\
\text { (i) Newspaper/Current Affairs } \\
\text { (ii) Scientific and technical periodical }\end{array}$ & 26 \\
\hline Tourism & 100 \\
\hline
\end{tabular}

Marangmei, Gaikhamdim; http://kanglaonline.com/2012/02/fdi-in-indias-retail-sector/

\section{Structure of Indian Retail Sector}

Retail is a sale for final consumption in contrast to a sale for further sale or processing (i.e. wholesale), a sale to the ultimate consumer. Thus, Retailing is the last link that connects the individual consumer with the manufacturing and distribution chain. A retailer is involved in the act of selling goods to the individual consumer at a margin of profit. However, in operations retail industry in India is dichotomously divided into exclusively organized and unorganized, Unorganized and local without establishment Retailing. Organized retailing refers to trading activities undertaken by licensed and integrated retailers, that is, those who are registered for sales tax, income tax and applying various modes and applications of marketing and operational integration. Excusive organized retailing comprises MNCs and corporate-backed hypermarkets and retail chains, exclusive departmental stores and also the individual and localized large retail businesses. Unorganized retailing, on the other hand, refers to the traditional formats of low-cost retailing for example, the local kirana (provision or grocery store) shops, sole-proprietor general stores etc. While various formats of individual disintegrated localized vending shops, convenience stores, hand cart and pavement vendors, etc constitute local without establishment retail shops and vendors. The Indian retail sector is highly fragmented on the basis of domestic geographical and socio-economic set up where most of the business is held by local retailers to fetch the need of localities.

Citing the structure of retail sector in India it is envisaged that application of FDI in any retail format is no issue but to identify the avenues of investment in suitable format and business. Mere statement that Indian retail industry has huge growth potential and mass consumerism in rural and urban segments in the last decade has attracted all big retailers to focus on India is not going to help in finalizing the road map for the FDI in retail.

\subsection{Avenues for FDI in retail}

The structure of retail in India is self driven and has its own ecosystem to thrive. Not whole of the retail is in need of the FDI. It is noteworthy that FDI in retail sector became the part of business strategies of Multi National Corporations (MNCs) and various countries interested to trade with India. The FDI in Indian retail can be explained on the basis of five types of FDI given by Chryssochoidis, Millar \& Clegg, $1997^{7}$ (see notes). Indian retail and FDI is firstly is type one of FDI as first type of FDI which is usually found in the countries like India is taken to gain access to specific factors of production, e.g. natural resources such as coal, land \& labour, technical knowledge, material know-how. Such factors of production are not readily available in many foreign countries, and are not easy to transfer therefore the foreign firm try to invest in India in order to secure access. Recent governments' initiative of 'Make in India' is also dwelling upon the first type of FDI. Make in India initiative also targets second type of FDI in which company shall invest in order to gain access to cheaper factors of 
production, e.g. low-cost labour ${ }^{8}$. However, third and fifth type of FDI are most talked issue in recent perspective of FDI in retail. The third type of FDI is especially being targeted for Retail sector involves international competitors undertaking mutual investment in one another, e.g. through cross-shareholdings or through establishment of joint venture, in order to gain access to each other's product ranges. The fifth type of FDI which is very recent in Indian Perspective relates to the trade diversionary aspect of regional integration. This type occurs when there are location advantages for foreign companies in their home country but the existence of tariffs or other barriers of trade prevent the companies from exporting to the host country. The foreign companies therefore jump the barriers by establishing a local presence within the host economy in order to gain access to the local market. The local manufacturing presence need only be sufficient to circumvent the trade barriers, since the foreign company wants to maintain as much of the value-added in its home economy ${ }^{9}$.

On the basis of types of FDI in any economy Indian retail would like to invite FDI in order to find employment for low-cost labour, to utilize available infrastructure, to acquire advanced retail formats and technology and to provide competitive edge to domestic retailers.

\subsection{Avenues and fear of FDI}

As per the FDI and its avenues in Indian Retail there are several fears and issues which are needed to be answered in order to provide necessary back up for the investment.

\section{How FDI In Retail Will Affect Different Segments}

\section{Small Manufacturers}

\section{IMPACT $\rightarrow$ Limited}

\section{WHY $\nabla$}

Retailers across the world like to work with a small group of select vendors for economies of scale. Nevertheless, the supplier base will be larger in number and smaller in turnover than elsewhere, because of regional diversity in consumption patterns.

\section{Infrastructure, Cold Chains}

\section{IMPACT $\rightarrow$ Very little \\ WHY $\nabla$}

Each retailer will invest only for what his own business requires.
Kirana stores

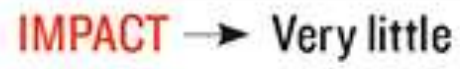

WHY $\nabla$

They operate in small towns and rural India, and serve the lower social class customers as well. Modern retail will target the top income layers in urban areas. In bigger cities, many kirana shops will morph and specialise, offering phone-in home delivery, e-commerce and the like.

\section{Jobs}

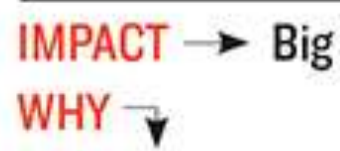

A new skill category called 'retail jobs' will be created. The birth of modern retail could improve wage rates in traditional retail.

Source: http://forbesindia.com/printcontent/33939

Fig 6 Forbes version of effects of FDI on retail

\section{Findings and Discussions based on Primary data collected by Researchers \\ 6.1 Customer Perception}

As per customer perception regarding organized retailing and application of FDI they were found concerned with various services and facilities at various stores in malls and markets. From data it is observed that there are many common areas of preference for customers in both local kirana stores and organized departmental stores. On the attributes and preference level for these attributes the number is quite large and absolutely significant to the attributive advantage at departmental stores and local kirana stores 
Table 2 Consumers Perception regarding stores

\begin{tabular}{|c|c|c|c|c|c|c|c|c|c|c|c|c|}
\hline Particulars & 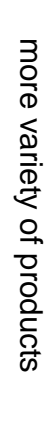 & 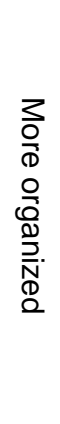 & 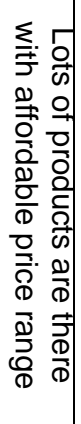 & 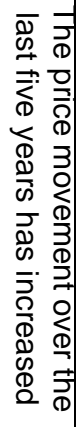 & 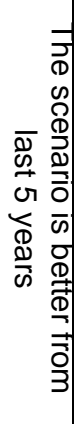 & 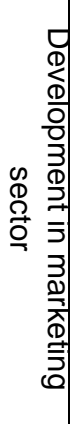 & 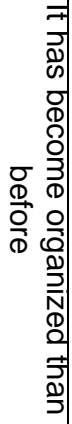 & 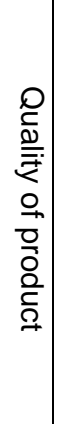 & 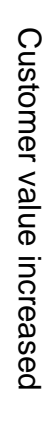 & 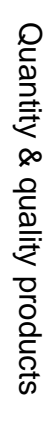 & 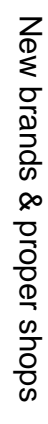 & 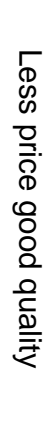 \\
\hline $\begin{array}{l}\text { Customers } \\
\text { visiting Local } \\
\text { Kirana Stores }\end{array}$ & $\square$ & $\square$ & $\square$ & $\square$ & $\square$ & $\square$ & $\square$ & $\square$ & $\square$ & $\square$ & $\square$ & $\square$ \\
\hline $\begin{array}{l}\text { Customers } \\
\text { visiting } \\
\text { Departmental } \\
\text { Stores }\end{array}$ & $\square$ & $\square$ & & $\square$ & $\square$ & $\square$ & $\square$ & & & & $\square$ & \\
\hline
\end{tabular}

Table - 3 Attributive features of Organised retail stores \& customers perception
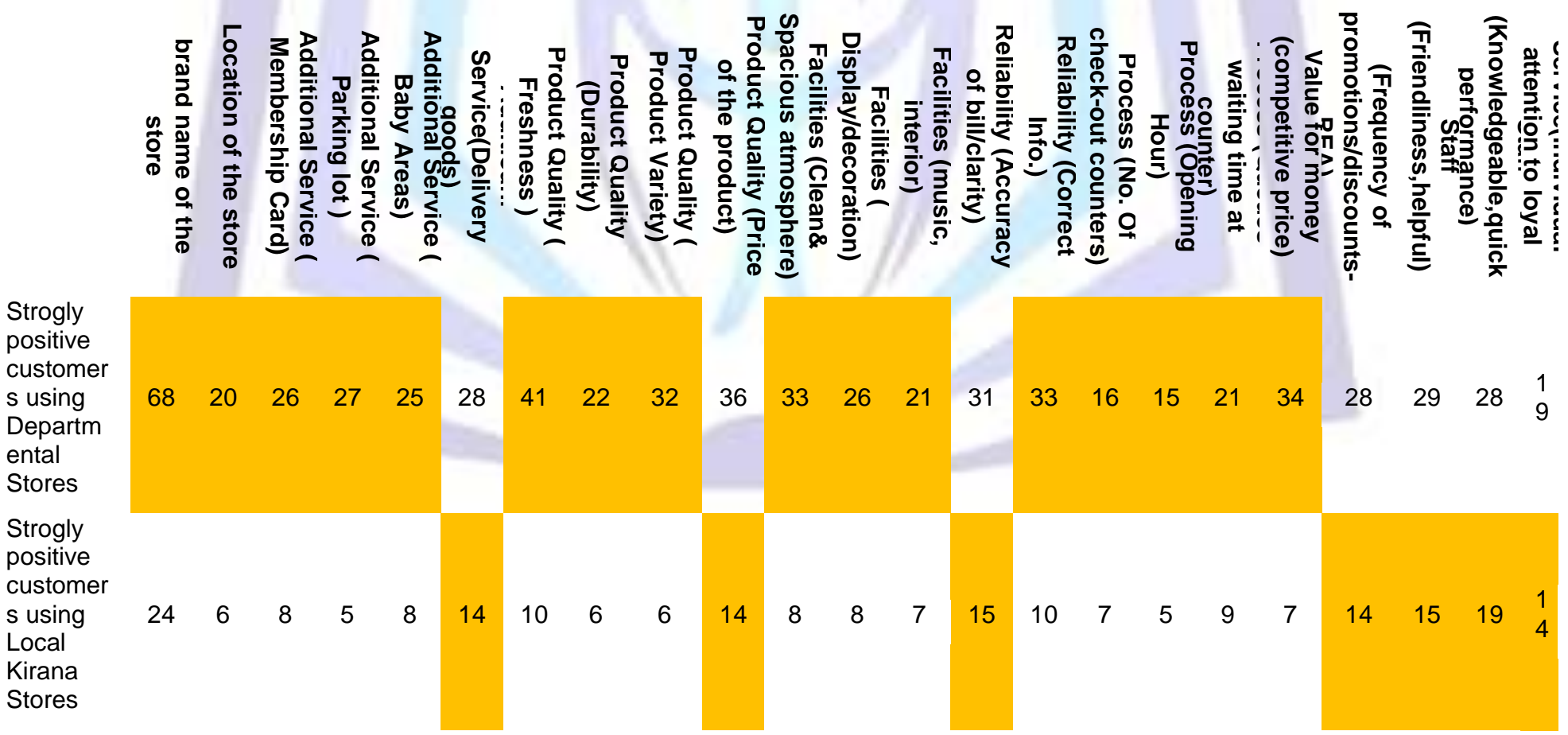

Out of 150 customers contacted 99 preferred departmental stores especially in malls and organized retail over local kirana stores. 


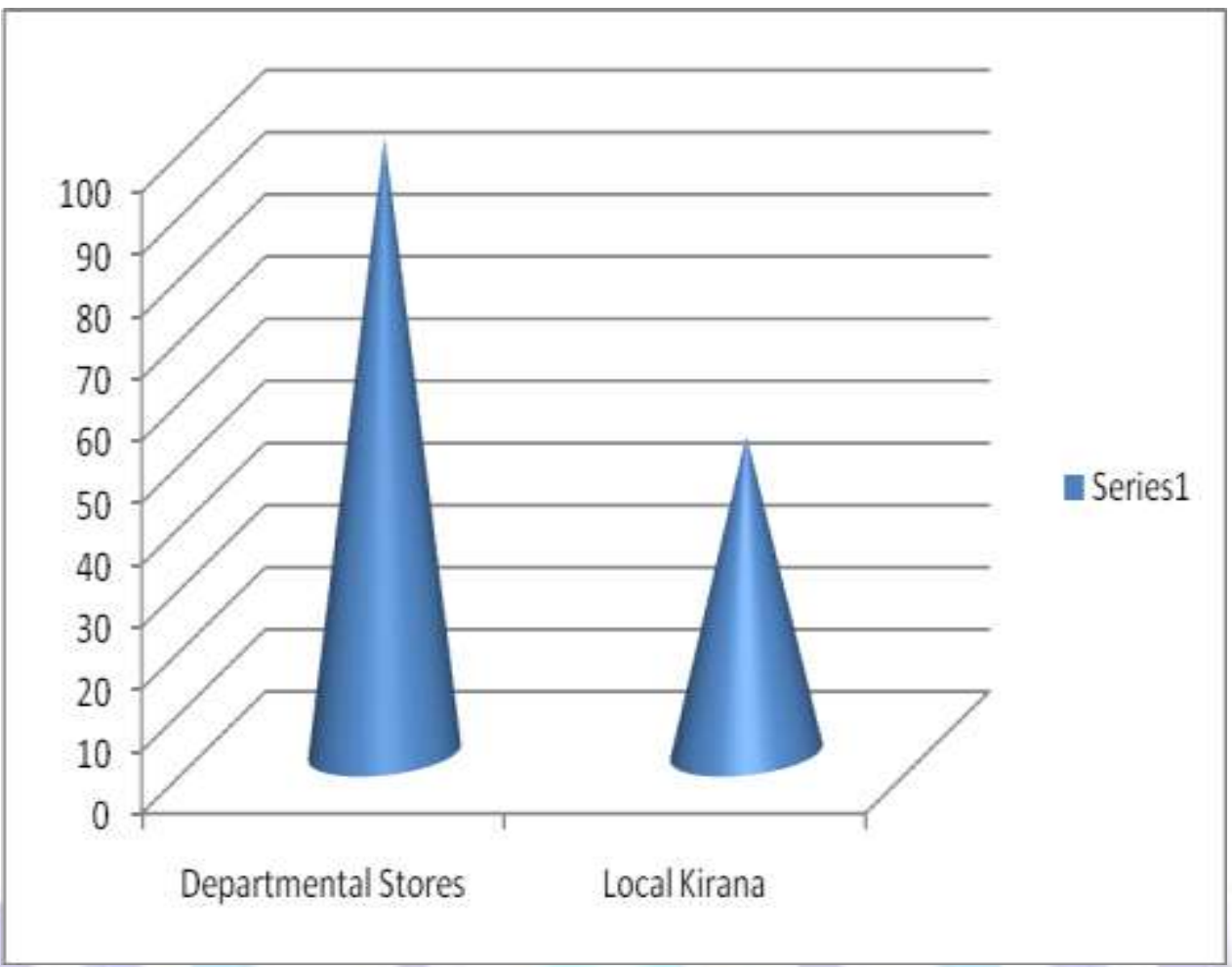

\section{Chart 1: Customer preference for stores}

Most of the customers are aware about organized and unorganized retailing and still are visiting both segments of retailing formats.

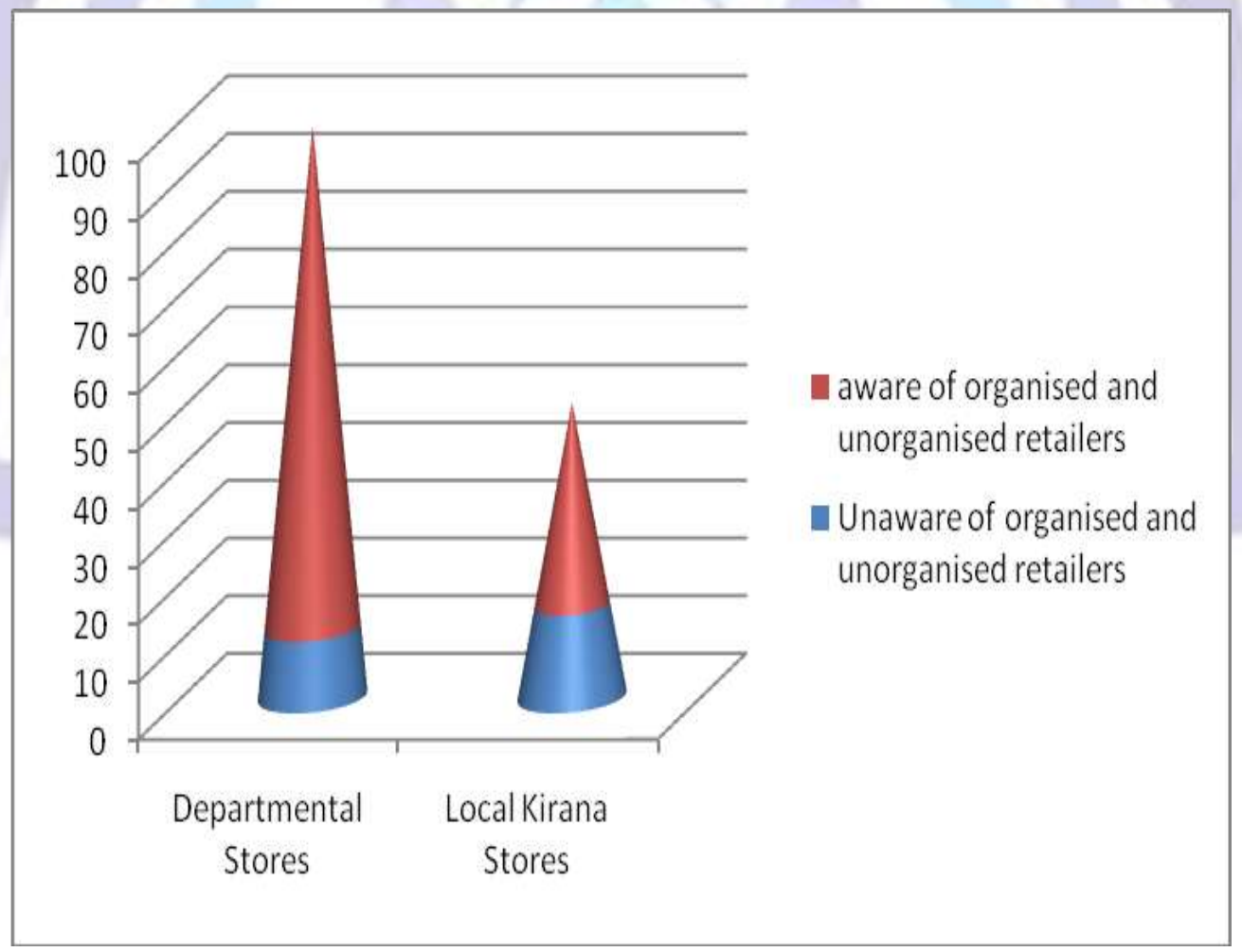

\section{Chart 2: Comparative Customer preference for stores and projections}

In the last 10 years of retailing in the city customers visits to the departmental stores are increasing vis-e-vis to visits to local kirana stores. 


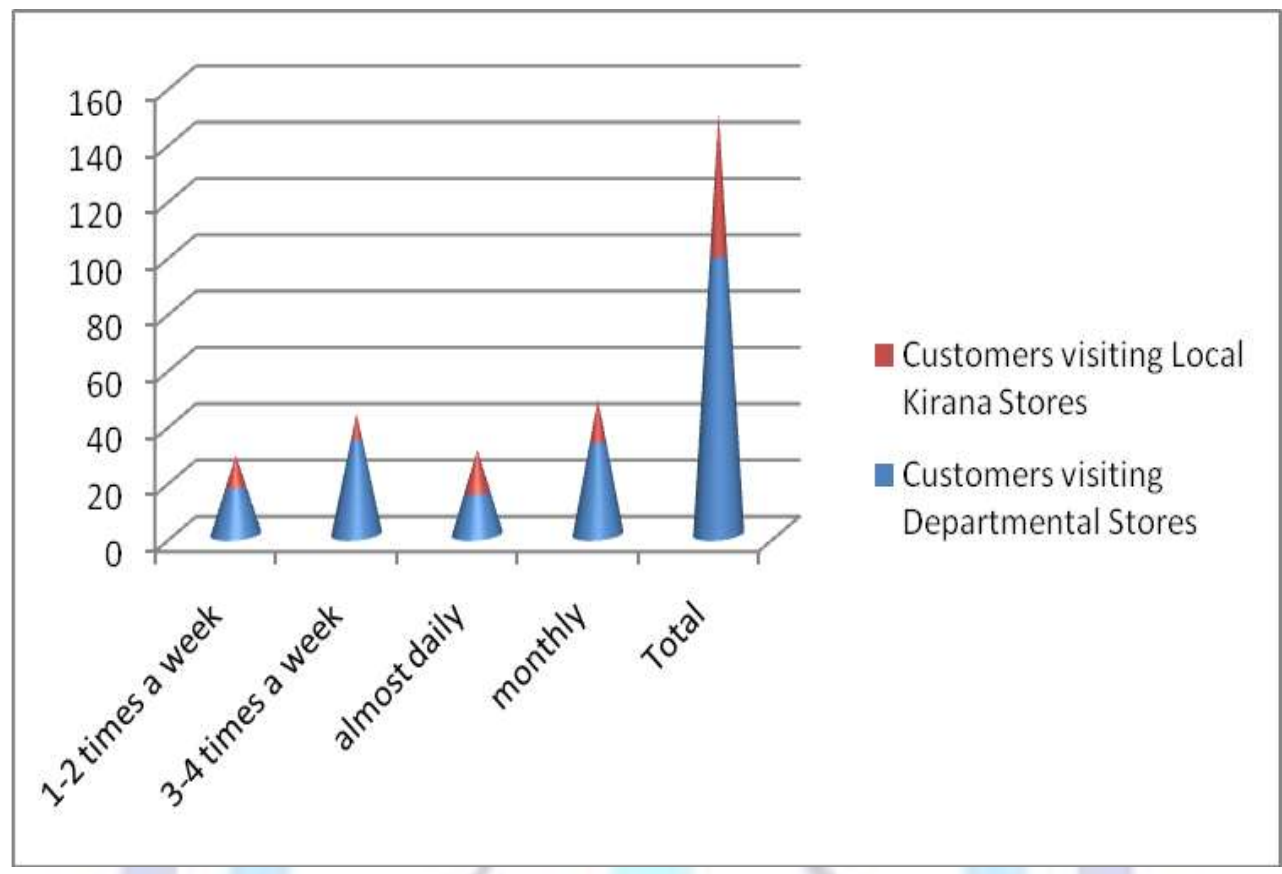

Chart 3: Customer visit to stores

The level of awareness is more skewed to the time period of stay in the city. Surprisingly customers who are new to the city have developed affinity to departmental stores fast as their less interaction with local kirana stores where service comes first over personal attention. As an observation personal attention was most significant criteria for preferring local kirana over organized departmental stores.

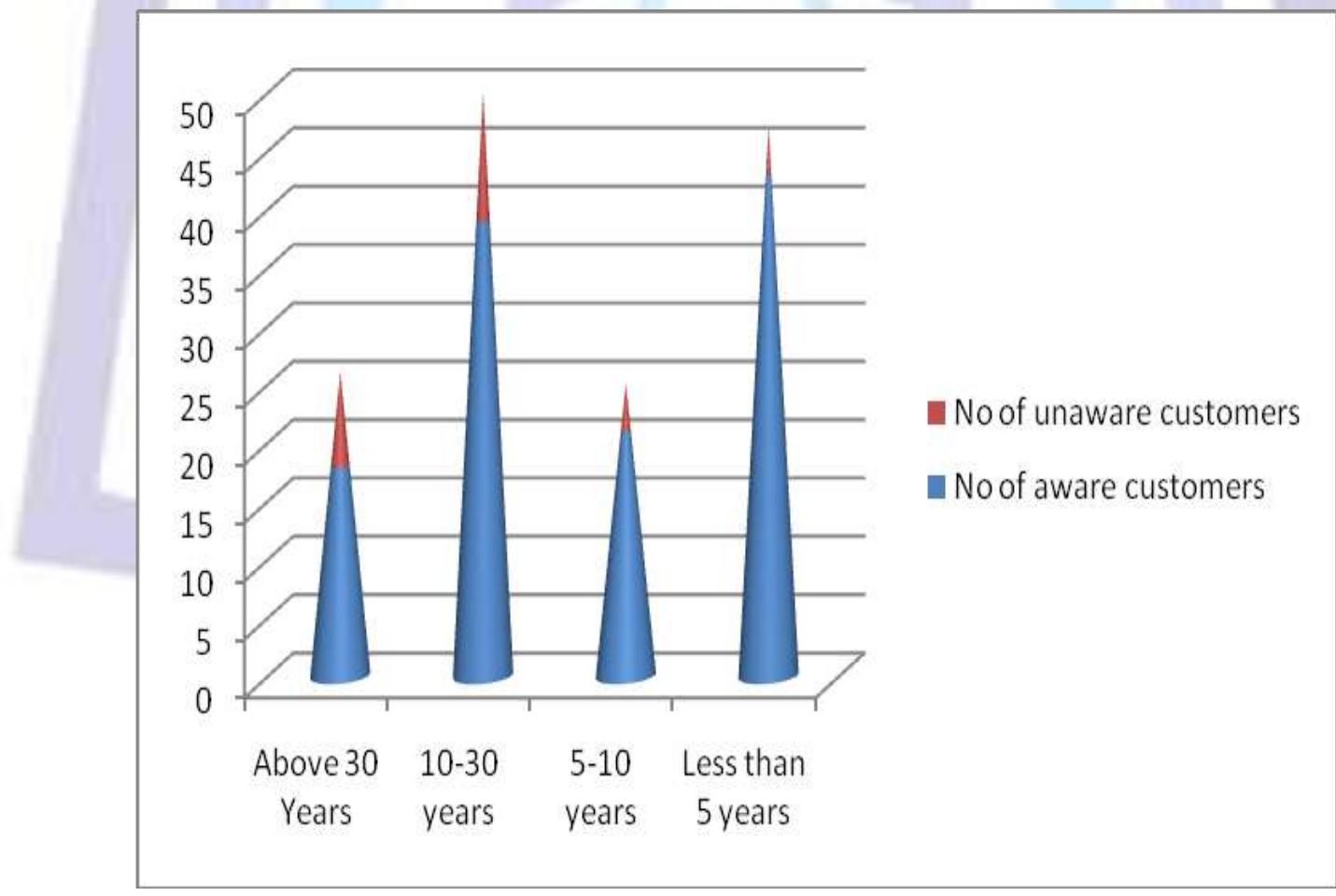

Chart 4: Awareness of retail formats

\subsubsection{Retailer's Perception}

From the retailer's point of view retailers having high volume of investment are most prone to competition from organized departmental stores in malls and focusing more to withstand. As evident from table they are expanding their premises to camouflage their presence to the masses as organized departmental stores. Such chain of stores is more common in the contemporary domestic retail segment in India. 


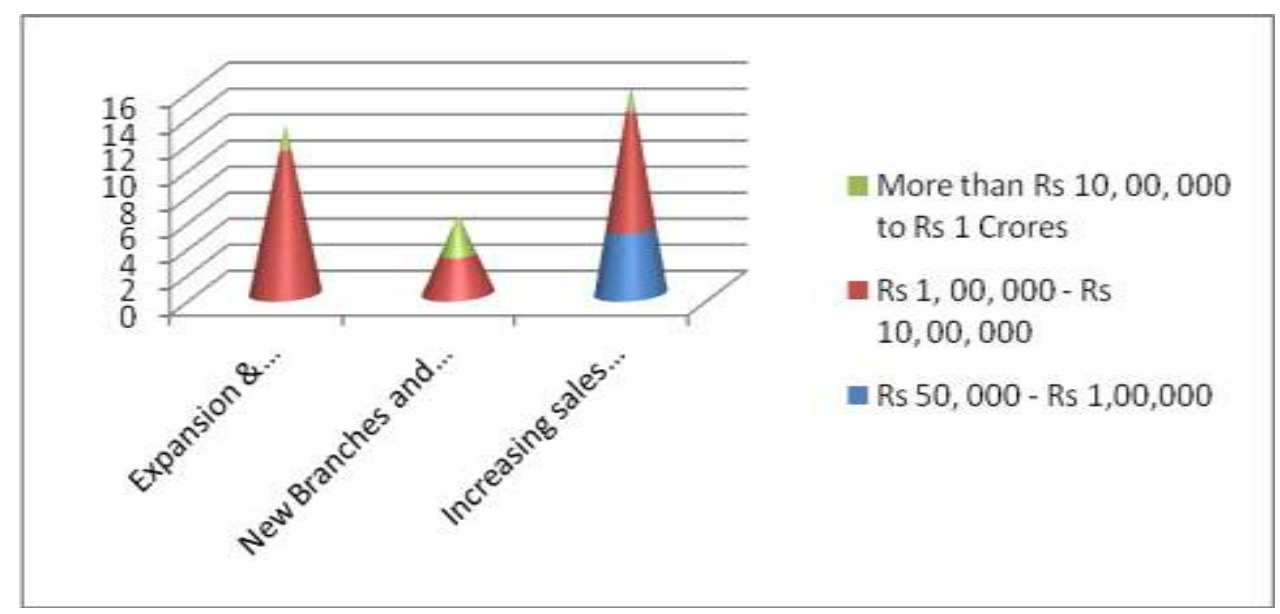

Chart 5: Retailer's Perception for expansion to take advantage of FDI in retail

\subsubsection{Perception of FDI}

Most of those retailers who have not expanded much and operating with huge investment accept that no of footfall may go down and also market share will be affected. However, retailers with investment lower than Rs 4 Lacks would see no considerable impact at all.

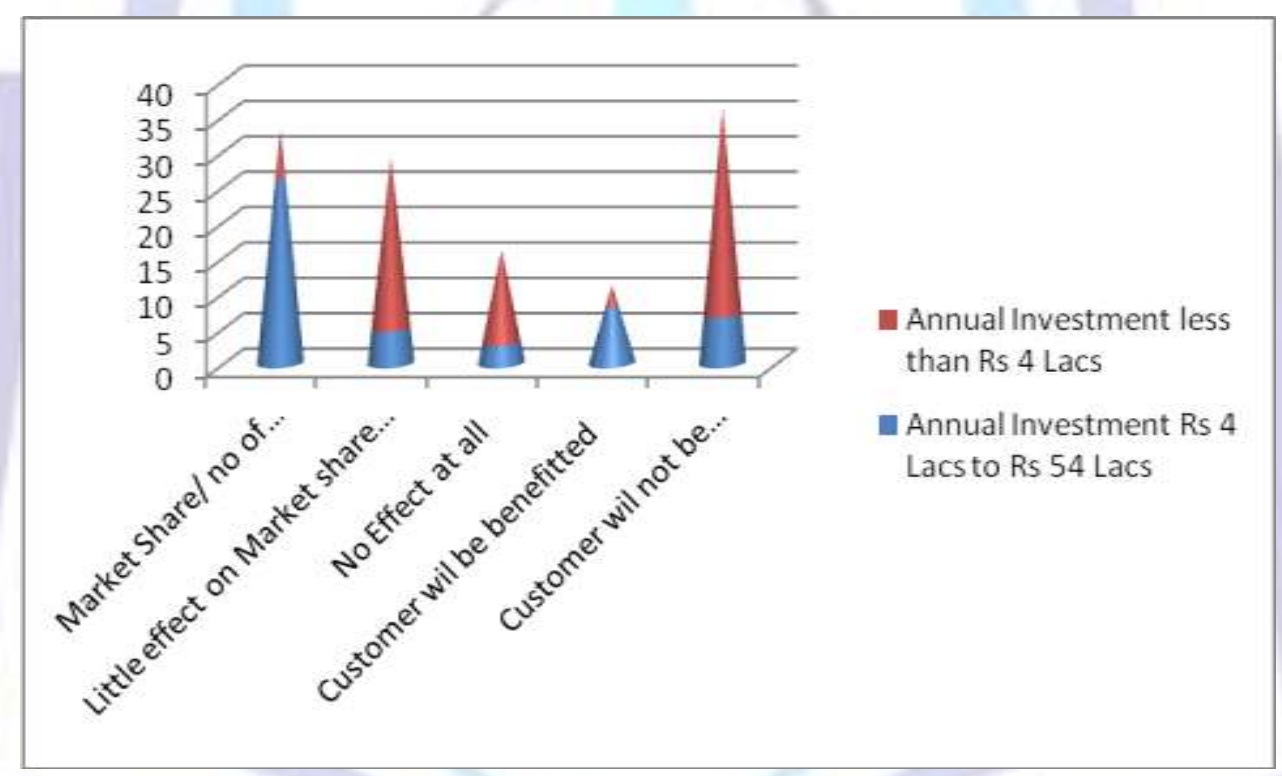

Chart 5: Retailer's Perception for effect of FDI in retail on their establishment and business

\subsection{Experts}

All of the experts from various domains are refuting any fear of job losses and loss of local entrepreneurs on account of FDI in single and multi brand retail segments rather they find significant improvement in the competitiveness and growth of all the sectors apart from retailing in India.

\subsection{Result \& Discussion:}

$\mathrm{R}^{2}$ value is significant to the dependent variable and location of outlets has positive correlation with brand name. Findings reveal preferred perception of all the respondents to the brands, organized retailers and quasi-organized retailers (domestic retailers camouflage the organized big retailers). It is also established that the retailers with large investment are more concerned with competition and their parallel growth and expansion to survive.

Table 4 Dependency of brand value on location, service delivery and product quality

Regression Summary for Dependent Variable: brand name (Spreadsheet1_(Recovered))

$$
\mathrm{R}=.08262440 \mathrm{R}^{2}=.00682679 \text { Adjusted } \mathrm{R}^{2}=-----
$$




\begin{tabular}{lllllllll} 
& \multicolumn{1}{c}{$\mathrm{b}^{*}$} & \multicolumn{1}{c}{$\begin{array}{l}\text { Std error } \\
\text { of } \mathrm{b}^{*}\end{array}$} & $\mathrm{~b}$ & $\begin{array}{l}\text { Std error } \\
\text { of } \mathrm{b}\end{array}$ & $\mathrm{t}(146)$ & $\mathrm{p}$-value & $\begin{array}{l}\text { R- } \\
\text { SQUARE }\end{array}$ \\
$\begin{array}{l}\text { Intercept } \\
\begin{array}{l}\text { Location } \\
\text { of Outlet }\end{array}\end{array}$ & 0.018637 & 0.089754 & 0.013070 & 0.062941 & 0.207649 & 0.835793 & 0.155562 \\
$\begin{array}{l}\text { services } \\
\text { delivery }\end{array}$ & 0.017906 & 0.089532 & 0.013406 & 0.067035 & 0.199991 & 0.841766 & 0.151369 \\
$\begin{array}{l}\text { product } \\
\text { quality } \mathrm{n} \\
\text { variety }\end{array}$ & 0.083864 & 0.084576 & 0.056181 & 0.056658 & 0.991578 & 0.323044 & 0.049007
\end{tabular}

Table 5 Correlation between brand name and location of outlet Correlations (Spreadsheet1_(Recovered))

Marked correlations are significant at $p<.05000$

Variable

$\mathrm{N}=150$ (Case wise deletion of missing data) Brand Name

Location

of outlet

\section{Limitations of the Study}

The major limitations of the presented study are given below:-

1. The primary limitation is the uncontrollability of some variables like cultural impact on the buying behaviour of customers.

2. There is possibility of sample respondent bias in their reporting of perceptual and attitudinal underpinnings on certain statements.

3. There is a problem in generalizing some findings as there are some unique variables at play.

4. The sample size may also be an issue as it may not reflect the true behaviour of the universe.

5. The study was conducted during January 2014 to February 2014 a period which is observed as the time of vibes operating against policies of incumbent government.

\section{Conclusion:}

The reason for initiating debate on the FDI in single brand and multi brand retail is obvious as this is going to be turning point for Indian Diaspora. In the presence of FDI not only living standard will improve but quality of retailing will also improve. The positive correlation confirms the perception of customers, retailers and experts for FDI in all the formats of retail in India.

\section{Notes:}

\section{Types of Foreign Direct Investment (FDI):}

According to Chryssochoidis, Millar \& Clegg, $1997^{6}$ there are five different types of foreign direct investment (FDI). The first type of FDI which is usually found in the countries like India is taken to gain access to specific factors of production, e.g. natural resources such as coal, land \& labour, technical knowledge, material know-how. Such factors of production are not readily available in many foreign countries, and are not easy to transfer therefore the foreign firm try to invest in India in order to secure access.

The second type of FDI which is also quite common in Indian Case is developed by Raymond Vernon in his product cycle hypothesis. According to this model the company shall invest in order to gain access to cheaper factors of production, e.g. low-cost labour.

The third type of FDI is especially being targeted for Retail sector involves international competitors undertaking mutual investment in one another, e.g. through cross-shareholdings or through establishment of joint venture, in order to gain access to each other's product ranges. As a result of increased competition among similar products and R\&D-induced specialization this type of FDI emerged. Both companies often find it difficult to compete in each other's home market or in third-country markets for each other's products. If none of the products gain the dominant advantage, the two companies can invest in each other's area of knowledge and promote sub-product specialization in production. 
The fourth type of FDI is seldom found in Indian Economy concerns the access to customers in the host country market. In this type of FDI there are not observed any underlying shift in comparative advantage either to or from the host country. Export from the companies' home base may be impossible, e.g. certain services, or the capability to request immediate design modifications. The limited tradability of many services has been an important factor explaining the growth of FDI in these sectors.

The fifth type of FDI which is very recent in Indian Perspective relates to the trade diversionary aspect of regional integration. This type occurs when there are location advantages for foreign companies in their home country but the existence of tariffs or other barriers of trade prevent the companies from exporting to the host country. The foreign companies therefore jump the barriers by establishing a local presence within the host economy in order to gain access to the local market. The local manufacturing presence need only be sufficient to circumvent the trade barriers, since the foreign company wants to maintain as much of the value-added in its home economy ${ }^{9}$.

\section{References:}

1. Shilpa Kumar (2014): 'Indian economy to grow better in the second half of 2014': Q\&A by Puneet Wadhwa; Business Standard, December 302013 cited on March 13, 2015

2. Dhoot, Vikas \& Prasad, Rachita (2014): 'Budget 2014: Finance Minister Arun Jaitley raises FDI in Defence from $26 \%$ to 49\%; ET Bureau, $11 \quad$ Jul, 2014, 24.48 AM http://economictimes.indiatimes.com/articleshow/38123695.cms?utm_source=contentofinterest\&utm_medium=te xt\&utm_campaign=cppst

3. Muthukumar Manikanda C., Subasri S. (2015): 'Foreign Direct Investment In Indian Retail Sector: Strategic Issues And Implications' International Journal of Management and Commerce Innovations; ISSN 2348-7585 (Online) Vol. 2, Issue 2, pp: (10-14), Month: October 2014 - March 2015, Available at: www.researchpublish.com

4. N.V.Shaha \& M.A.Shinde (2013). "FDI In Indian Retail Sector: A Critical Analysis" Tactful Management Research Journal ISSN: 2319-7943 Vol. 1, Issue. 5 , Feb 2013

5. Gaurav Bisaria (2012). "Foreign Direct Investment In Retail In India" International Journal of Engineering and Management Research, Vol. 2, Issue-1, Jan 2012 ISSN No.: 2250-0758 Pages: 31-36

6. Himani Tyagi (2012). "Impact Of FDI In Retail - Boon Or Curse" VSRD International Journal of Business and Management Research, Vol. 2 No. 12,December 2012 ISSN No. 2231-248X (Online), 2319-2194 (Print)

7. Chryssochoidis, George; Millar, Carla; Clegg, Jeremy (1997): 'Internationalization Strategies. Palgrave ISBN: 9780333629543 Herb Tandree Philosophy Books Stroud, UK, United Kingdom

8. Mukane, Pratik (2014): Highlights of Make In India launch: Narendra Modi woos India Inc; dna webdesk, New Delhi; Thursday, 25September 2014 - 1:00pm IST | Agency: http://www.dnaindia.com/india/report-live-primeminister-narendra-modi-to-launch-make-in-india-initiative-today-2021424

9. B.Udaykumar (2012): ' A Conceptual Framework on Foreign Direct Investment In Retail Sector - India'; Asia Pacific Journal of Marketing \& Management Review ISSN 2319-2836 Vol.1 (4), December (2012) www.indianresearchjournals.com pp 87-88

10. Suzana Stefanović (2008): 'Analitical Framework Of FDI Determinants: Implementation Of The Oli Model'; Facta Universitatis Series: Economics and Organization Vol. 5, No 3, 2008, pp. 239 - 249 UDC 339.727 .22

11. Ajaz Ahmad and Suresh Mayya (2012). "Impact of Shopping Malls on the Unorganized Retail Sector: A Case Study of Mangalore Region, Indian Journal of Marketing, September 2012, p.31-40.

12. GONG Xue (2008), “The Impact of FDI and Technological Innovation on Eastern, Middle and Western China's Economics" International Conference on Management Science \& Engineering (15th) September 10-12, 2008 Long Beach, USA

13. Badrinath. V (2012), "FDI in Indian Multi Brand Retail Sector- Should the Government hold back or roll back the proposal?" International Conference On Advances In Engineering, Science And Management (ICAESM -2012) March 30, 31, 2012

14. Chris Devonshire, Ellis \& Srivastava, Ankit (2012): 'Foreign Direct Investment in India's Single and Multi-Brand Retail'; www.india-briefing.com; February 2, cited on April 7, 2014 at 11 AM

15. Gnanendra. M \& Jyothi. P.M. (2012): 'Emerging Issues of FDI in India'; http://www.indianmba.com/Faculty_Column/FC1533/fc1533.html

16. Gaikhamdim Marangmei (2012): 'FDI in India's Retail Sector'; February 15. http://epao.net/epSubPageExtractor.asp?src=education.Jobs_Career.FDI_in_India_Retail_Sector

17. Rama Bijapurkar, R Sriram, S Raghunandan (2012): Decoding The Detail In Retail Why there is no need for great celebration or for deep despair over FDI in retail Oct 22, http://forbesindia.com/article/boardroom/decodingthe-detail-in-retail/33939/1\#ixzz2yYHWzgn2 . 